\title{
Cultural Revolution
}

and Revolutionary Culture 
This page intentionally left blank 

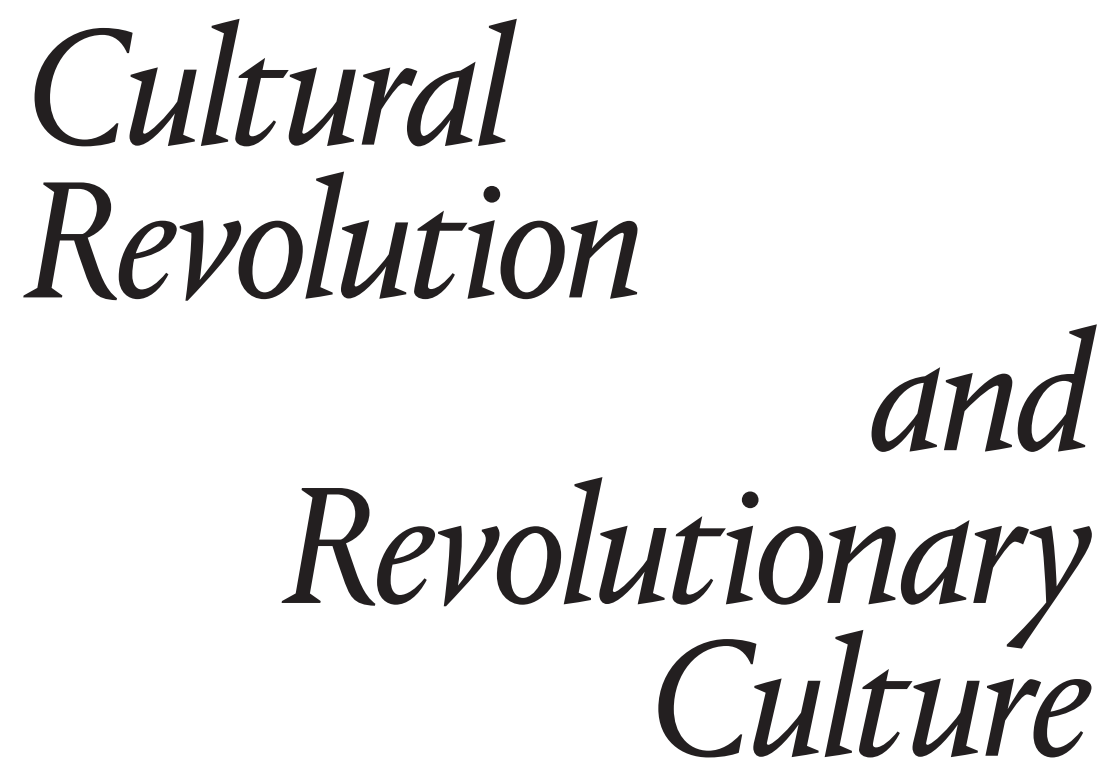

Alessandro Russo

Duke University Press Durham and London 2020 
(C) 2020 Duke University Press All rights reserved

Printed in the United States of America on acid-free paper $\infty$ Designed by Drew Sisk

Typeset in Portrait Text by Westchester Publishing Services

Library of Congress Cataloging-in-Publication Data

Names: Russo, Alessandro, [date] author.

Title: Cultural Revolution and revolutionary culture / Alessandro Russo.

Description: Durham : Duke University Press, 2020.

| Includes bibliographical references and index.

Identifiers: LCCN 20I9054783 (print) | LCCN 2019054784 (ebook)

ISBN 978I478008590 (hardcover)

ISBN 978I478009528 (paperback)

ISBN 978I4780I2I84 (ebook)

Subjects: LCSH: Political culture-China-History. | Communism and culture-China. | China-History-Cultural Revolution, 1966-1976.

Classification: LCC DS778.7 .R87 2020 (print) | LCC DS778.7 (ebook) | DDC 951.05/6-dc23

LC record available at https://lccn.loc.gov/2019054783

LC ebook record available at https://lccn.loc.gov/2019054784

Cover art: Claudia Pozzana, Veiled Mao. Shanghai, 2009. 